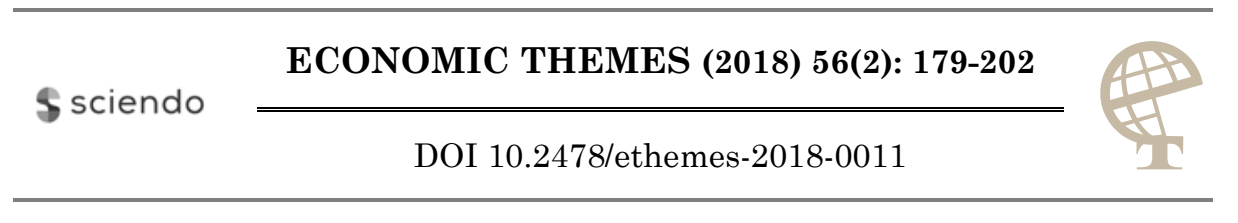

\title{
CONTACTLESS TECHNOLOGY AS A FACTOR OF TOURISM INDUSTRY DEVELOPMENT - A REVIEW OF CURRENT PRACTICES AND FUTURE DIRECTIONS
}

\author{
Nataša Dragović \\ Student of Department of Geography, Tourism and Hotel Management, \\ Faculty of Sciences, University of Novi Sad, Republic of Serbia \\ $\triangle$ natasadragovic777@gmail.com
}

\section{Uglješa Stankov}

Department of Geography, Tourism and Hotel Management, Faculty of Sciences, University of Novi Sad, Republic of Serbia

$\bowtie$ ugljesastankov@gmail.com

\section{Đorđije Vasiljević}

Department of Geography, Tourism and Hotel Management, Faculty of Sciences, University of Novi Sad, Republic of Serbia

$\bowtie$ dj.vasiljevic@dgt.uns.ac.rs

UDC

338.48:

621.396

Review paper

Received: 29.01.2018

Accepted: 28.05.2018
Abstract: During the Second World War, technology was developed for tracking objects or enemy aircraft, now known as contactless technology, which at that time was limited to only one type of technology, called RFID - Radio Frequency Identification. For years, contactless technology has evolved and NFC technology has emerged from RFID technology, which is labeled as short-field technology. Today, Bluetooth Beacon technology is also known and developed. All three technologies have a great application in tourism, such as contactless payment, toll collection, sharing of important information, access control, exchange of data between two smart devices, as well as many others. The aim of this paper is to indicate the significant application of contactless technologies in tourism, as well as to highlight the benefits and future implications of the examples presented.

Keywords: contactless technology, RFID, NFC, Bluetooth Beacon technology, tourism, tourism development.

JEL classification: O3, L83, Z32 


\section{Introduction}

In many respects, technology had a major impact on the development of the tourism industry, mainly until the 1980 s, we can talk about a revolution in the process of distribution of tourism products, communication with consumers and between business entities, creating a destination image, accessing information, reducing the prices of tourism products, transport safety, market competition and customer relationship management (CRM).

According to Buhalis (1998), the development of technology is at the same time a driver of the tourism industry for many reasons. Technology has affected the costs, marketing, government and competitiveness of the participants in tourism. When it comes to costs, technology has influenced the price flexibility, lower costs of labour, lower costs of distribution of products and services, or increased the efficiency of overall costs in the tourism industry. Also, through technology it is possible to satisfy even the most demanding consumers, provide precise information, respond quickly to fluctuations in the market of demand, support research in marketing, and provide support from the government and other state institutions that in a certain way facilitate the functioning of tourism as an industry of importance.

The development of technology has affected almost all types of tourism, including medical tourism, because patients travel from less developed countries to developed ones to heal. The reason for this is technology, which is much more advanced in developed countries (Kahveci \& Okutmus, 2017).

It is anticipated that contactless technology will experience even greater development in the coming years and is likely to affect tourism as an industry, but also in the science-research field related to tourism.

The subject of research of this paper is the presentation of different ways and possibilities of the use of contactless technologies in tourism. Review will focus on a network with the least reach that can be most significant in various tourist spheres. The RFID technology will be analysed through its basic use, NFC technology and its wide application in tourism, as well as Bluetooth Beacon technology.

In the last few years, contactless technology has made great progress when it comes to tourism. The aim of the research is to present the potentials of contactless technologies in tourism through theoretical and practical analysis. Also, the goal is to present the application of contactless technology so far on different examples and to identify possible shortcomings, i.e. positive and negative impacts on tourism development and tourists.

First of all, the paper should explain what the contactless technology is and why it came to be. Then, the task is to present case studies that testify the use of 
contactless technology in tourism. Methods of research include the scientific and professional literature, other written documents, as well as documents in electronic format and Internet data sources. Within the empirical methods will be used graphic, quantitative and critical methods.

\section{Basics of contactless technology}

Information and communication technologies play a key role in the competition of destinations. It affects consumers to find and buy such tourist arrangements that will help develop technology and generally globalisation of industry in order to develop it in a wider area. In addition, technology enables and supports the development of marketing in a variety of ways, which actors in the tourism industry need to recognise and utilise in order to be successful in achieving their goals in terms of consumers, profit in business and market reputation (Buhalis\&O'Connor, 2005).

With the development of smart technologies, people are increasingly using smart devices to ease everyday obligations, communication with friends, and business communication. The use of mobile devices in relation to other devices has also increased, as they are easily transferable, and they can provide almost all operations that are enabled by the personal computer. Since the contactless technology is relatively new, it is still working on its improvement, but also on expanding its application ( $\mathrm{Du}, 2013)$. This is evidenced by examples of the use of this technology in tourism that are presented in the following chapters and on the basis of which we can conclude that they have much to offer us.

\subsection{RFID technology}

Radio Frequency Identification (RFID) is a remote data sending and receiving system using RFID tiles or transmitters. In the last decade, RFID technology is slowly emerging from its shadow due to its speed as one of the advantages and is becoming widespread in managing supplies of goods and materials. This technology does not require the visibility of the product itself to recognise it but it works remotely. Tags used by this technology are made up of a set of unique IDs and can provide data such as product names, type of goods, quantity of goods and materials, as well as to measure external factors such as air humidity. There are several types of RFID tags, but the basic division is active and passive. Active tags must have some power source, so that they can connect to the power infrastructure or use energy from an integrated battery. Therefore, an active tag with a built-in battery is limited by the number of operations that one battery can support. These labels are not as practical as the power supplies are expensive. Passive tags are widely used because they do not require any power supply, have an unlimited lifetime and are small in size. Passive tag consists of three parts: an antenna, a chip, 
and some form of attribute protection and tag function. The power of a passive tag is enabled by a tag reader, which also communicates with tag (Want, 2006).

Three functions are supported by RFID technology and it depends on the type of transponder memory:

- Read Only $(\mathrm{R})$ - reading a transponder that gets its unique serial number in the production process. Once stored information cannot be changed.

- Write Once Read Many (WORM) - the user is programming the memory of the transponder, but the data can only be entered for the first time, after which it remains permanently stored.

- Read-Write $(\mathrm{R} / \mathrm{W})$ - the user can record information on the transponder many times. Read-write transponders usually have a serial number that cannot be deleted and the entered data is added to it. Read-write transponders are useful in more complex applications, but since they are more expensive, they are not practical for labeling low-cost products (Kaur, Sandhu, Mohan\& Sandhu, 2011).

The frequency determines the speed of reading and data exchange. The higher the frequency the faster the transmission. This information is significant in the planning of the RFID system, especially where the transponder will quickly pass through the reading zone. The extent of the transponder signal depends in part on the frequency domain. There are other factors - reader power, interference generated by objects in the environment (especially metal) and other RF devices. Typically, the range of passive transponder (without batteries) of low frequency is $30 \mathrm{~cm}$ or less, high frequency transponders can be read from a distance of about 90 $\mathrm{cm}$ or less and UHF transponders with 3 to $6 \mathrm{~cm}$ (Sen, D., Sen, P. \& Das, 2009).

\subsection{NFC technology}

In 2002, two major companies, Sony and Philips, united their forces to produce new wireless technology, which will enable two smart devices to interact with each other. A year later, this plan is being realised, when appeared NFC technology, based on short-field communication. For this technology, the ISO/IEC18092 standard has been adopted, which will serve as a basis for the functioning of NFC technology. Finally, in 2004, these two companies established a forum, closely specialised in NFC technology, which carries out marketing and technology enhancement activities. NFC technology is based on labels, which represent information memory for reading by smart devices that are also accompanied by this technology (http://www.nfc.cc; Violino, 2014).

The first mobile device supporting NFC technology was the Nokia 6131, and the first device with the Android operating system was the Samsung Nexus S. NFC technology began to develop more and more, which influenced the emergence of new applications such as sharing information, data, files between smart devices that support this technology (Denso, 2010; Vazquez-Briseno et al., 2012: Michelle, 2013). 
According to Ok, Coskun, Aydin and Ozdenizci (2010), NFC is a technology that works at a very short distance, which has been developed from radio frequency identification technology, which makes it very easy to use. Compared to other technologies NFC has very fast set-up time and better usability, more use cases and better consumer experience. Madlmayr and Scharinger (2010) also compare NFC with Bluetooth, Wi-Fi and RFID. According to them the advantage of NFC compared to Bluetooth and $\mathrm{Wi}-\mathrm{Fi}$ is the fast and automated connection. However, NFC could be used to set up a Bluetooth or Wi-Fi connection automatically. In this sense NFC would serve as an enabler for Bluetooth or Wi-Fi. In contrast to RFID, where the focus is on identification, NFC is based on interaction.

Ok et al. (2010) have presented three ways of working NFC technology: Peerto-peer, Reader/Writer and Card emulation. They claim that (p. 335): "In cardemulation mode the data is transferred from mobile-device to NFC-reader; in reader/writer mode data is transferred from NFC tag to mobile device or mobile device to NFC tag; and in peer-to-peer mode data is transferred between two NFC compatible devices."

As well as RFID technology, NFC technology works in both active and passive communication. Active communication involves communication between the initiator and the target device. In this way, two devices can interact with each other and exchange data. Communication initiates an active device called the initiator and thus sends a message to a passive device that can be activated only when it accepts the call for communication. Acceptance of the call for communication takes place only for the first time when the devices communicate. Every next time devices are automatically connected because communication has been previously approved. Nonetheless, the communication device is still considered as an initiator, but both devices can be both the initiator and the target device. In this mode of communication, both devices have battery power. During communication in a passive field, the device communicates with the mark via radio frequency fields. In practice, the passive way of communication is used more. For a passive tag, i.e. for communication with the device, no power source is needed. However, the device that triggers this communication is both passive and active (Kevin et al., 2012).

There are many possible ways to use NFC technology in the travel industry: paying with smart credit and debit cards and also with smart devices using software such as Android Pay, Apple Pay, Google Wallet; providing information through smart posters, tags in cultural objects such as museums in London, Frankfurt; providing access to certain facilities such as stadiums, but also to hotel rooms using a smart phone as a key; free access to the Wi-Fi network by scanning a label that contains the necessary information (password); discount cards for loyal guests that can be operated with a smartphone; payment of a coupon for city transport by smartphone; providing location-based information (Okazaki \& Hirose, 2009). 
Based on the above, it can be concluded that NFC technology has many advantages. First of all, smartphones have a dual role, and that's reading and storing information. NFC technologies also support the entire RFID system, since they are also generated by RFID technology. In addition to the easy-to-use application available to everyone, NFC technology is very well protected from hacking in communication processes between devices because it cannot perform activity if devices are more than four centimeters away (Ok et al., 2010).

\subsection{Bluetooth Beacon technology}

In order to connect the data available everywhere and smartphones in the easiest way, beacons are created to solve this problem. Beacons are placed in places of importance, i.e. where the greatest fluctuation of tourists is to enable them to get information. By turning on the Bluetooth on the smartphone, the user gets information. Also, beacons can also install applications on our device and interact (Stamenkovic, 2016).

Since smartphones with iOS and Android are the most used today, so beacons are created for both systems, iBeacon and beacon. Beacons enable applications to respond to signals they send and respond to. This technology makes it possible for people to make the most of their time in a particular location, which is why they are set up at resorts and similar places (www.ibeacon.com).

Bluetooth Low Energy (BLE-based beacon) is a technology that enhances existing Bluetooth technology in the use of operations that use minimum energy. One of the advantages of beacons is that they do not require internet access because their system functions in a simple mode of operation that does not require an Internet connection. First of all, this technology was created for retail facilities, but in time it has expanded its application to the tourism industry and has proved very well in restaurants, hotels and other facilities. Also, beacon technology is very precise because it can identify the device at a few inches (Stamenkovic,2016).

There are many ways to set the beacon hardware. With a simple protocol, everything the beacon needs to do is transfer its UUID, the master number and the secondary number in the fixed interval. Any device with Bluetooth 4.0 and later versions is capable of behaving like a beacon, whether it is a software application on a laptop, mobile device or a host computer with a USB interface. Creating a beacon does not require a specialized type of hardware. There is hardware specifically dedicated to beacon hardware and general-purpose hardware. The advantage of the hardware dedicated to beacon is that they are optimised for beacon tasks (Stamenković, 2016; Gast, 2015).

Beacon technology has been adopted in recent years between different domains, from retail to education, museums and tourism. The retail industry is the 
leader in the implementation of beacons, but tourism also had an impact on the development of this technology:

- Passengers can navigate to their departure gate/area, find the closest restaurants and restrooms and locate nearby retailers.

- Travelers can opt to automatically receive location-aware alerts, including coupons and special promotions, from airport and terminal retailers and restaurants.

- The airport and terminal application can alert passengers when it is time to get to the boarding gate.

- Through analytics, you can send application users information about the shortest security lines.

- Provide hotel guests with easy-to-use, fast check-in.

- Identify your most loyal guests and automatically send a greeting to their smartphones as they arrive or thank them for their stay as they depart.

- Guests can easily navigate to their rooms or the hotel restaurant, fitness centre or swimming pool, as well as locate nearby stores and restaurants.

- Offer coupons and special promotions.

- Make a game of a guest's stay with location-aware rewards.

- Use analytics to help guests find the shortest check-in or other lines.

- Identify customers by name as they arrive and ask if they would like to order menu items they have previously purchased.

- Help enable diners to place an order from anywhere and pick it up in the restaurant or the drive-through window.

- Offer incentives to encourage previous customers in proximity to return to your restaurant.

- Use analytics to understand how many previous customers have passed by the restaurant, how many placed an order, and how one restaurant location's traffic compares to another in the brand (Stamenkovic, 2016; Babu, 2015; www.cisco.com).

A large number of useful functions can be covered by beacons. In addition, through applications with enabled beacon, users can enter their individual preferences and comments, which can mightily help to maintain the best possible relationship between the hotel and the guest (Stamenkovic, 2016).

\section{Testing}

Madlmayr and Scharinger (2010) presented several examples of the use of NFC in tourism. The first is field work in Hanau, Germany. In this test, the public transport system is used to make the bus timetable available via NFC, as well as integrate a pay-based payment system based on RFID tags. A smartphone application has been created to view the schedule of the drive. In addition, they presented a project on 
the tourist island of Silt (Germany), where a tourist guide was developed through NFC technology. On the island are placed RFID tags, on tourist attractions, local restaurants and meeting places. When the phone is moved in front of the tag, a web page is automatically opened with detailed information. The third example presented is the navigation system, which uses RFID positioning tags and an application that allows navigation system to be available when there is no Wi-Fi connection. The examples described demonstrate the different potentials of NFC technology in tourism. Nonetheless, they only use reader/writer mode. These authors end their study with the advice that a tourist destination should only use one application and coordinate its NFC services so that logos inform the guests of the options and help them avoid confusion.

All-I-Touch is an NFC application related to tourism, described by Kneissl, Roottger, Sandner, Leimeister and Krcmar (2009). They believe that NFC technology has multiple uses, but also has a significant social component. In order to emphasize the social significance, the created application makes it possible to set the status on social networks. This activity can be carried out by waving the phone in front of the label.

In France, several tests of NFC technology were conducted. In June 2010, the first public release was launched in Nice, called Cityzi. It is coordinated by the French Association of Contactless Devices. In this case, several mobile operators, a certain bank, and public transport in Nice took part. In order to test the system, mobile operators are selling 4000 phones with NFC technology for sale. The goal of the project was to enable tourists and residents to pay public transport using NFC technology phones, to use smart posters to obtain tourists with information and to have access to an updated schedule of buses and trains. It is even possible to purchase in certain stores and to obtain loyalty points (Balaban, 2010). The term "NFC" was not used in public, during the case study. The project was run under the name Cityzi and four logos were made indicating the availability of different services. These logos can be used for marketing purposes and for informing the public about standard services. For the public, a website has been created with the options offered by Cityzi. The web site lists four main options: payments, transportation, information and bonuses. According to Clark (2010), he considered that the pre-commercial test would collect information and help develop business models for future commercial projects. It is planned to extend the system to other parts of France. The French government has offered funds to cities investing in NFC technology. Nine cities received funding in January, 2011. In October of the same year, 42 cities across France responded to the funding offer (Clark, 2011a).

Today, this programme is used by 2,5 million people in France. The programme enables payment during purchase, public transportation tickets, access to user services of loyalty programmes, access to local information, entry into facilities (such as stadium or business building). 
Internet Corporation Google has launched tests on NFC technology in three cities in the United States. From December 2010 to March 2011, Google presented the marketing system on the market in Portland (Oregon), Austin (Texas) and Las Vegas (Nevada). For visitors it was supposed to be a tourist pocket guide. Visitors could find or write recommendations by waving the phone over the sticker or scanning a barcode with a camera of a mobile phone (Brown, 2011).

In addition, all data from the Google Places site, such as working time, sales, contact information or other data, were immediately available to users without the need for a restaurant or store. Availability is achieved by simply holding the phone, which supports NFC technology, via the sticker. Within the Google Places application, several Google services are combined to give the visitor the opportunity, for example, to compare the restaurants using the Google Maps and move to a specific location (Gallaga, 2011).

The idea of the project consists of a smartphone application called Near Field Communication Smart Tourist Card or abbreviated NFC SMTC, as will be indicated in the continuation of the text. Tourists who visited Italy at that time could use different services through NFC technology. One of the services was a mobile wallet that the user could use for all payments during the stay. Part of the project was not just payment cards,i.e. mobile wallet as well as other virtual cards that enabled certain discounts, bonuses, location-based services, maps and etc. (Basili, Liguori\&Palumbo, 2014).

Part of this project were not only tourists, but also local citizens, government, telecommunication operators, tourist organizations, tourist associations, all possible participants in the tourism industry in one region. This smart card is conceived as a personal travel assistant, which will enable more activities that make up one trip from preparing for a journey to return home (Basili et al., 2014).

There is no mistake if we consider this card as very useful, due to the large number of services it provides. Also, this example is very good in terms of showing the synergy of more organisations that are out of tourism, with the tourism industry itself and in that way, manages to create a unique smart card for tourists and citizens.

Clarion Hotel in Stockholm is the first hotel to use NFC technology to replace hotel room keys. For this test, the Assa Abloy Access Control Company, the "TeliaSonera" mobile network operator, the Ving Card Elsafe key wizard specialist and the Vonyon TSM provider have joined forces. The trial was launched in November 2010 and lasted eight months. During the trial, 30 loyal guests received phones that support NFC technology. When booking a hotel, the confirmation is sent to their mobile phones. Prior to their arrival, they reminded them to check-in electronically using mobile phones. Using a special application, it is enabled to use the mobile phone as a key from a room. Therefore, the check-in at the reception was not necessary. The check-out could also be carried out without going to the reception by swiping the phone in front of the RFID tags located in the hotel or via 
an application on a mobile phone. After check-out, the digital key that has been used is automatically deactivated. The activated mobile device can be locked away, if it is lost or stolen. The aim of the trial was to gather information from guests and employees. Therefore, the trial is followed by research. According to this study, the most preferred advantage was the time saved in the process of check-in and checkout. Guests were also interviewed for additional NFC applications at the hotel. Most of the participants in this survey mentioned the option of paying beverages, food and other services via mobile phones. The other mentioned applications were maps and information on gym, restaurants, bars and public transport. The advantage of this NFC system is that it also works with existing RFID locks. However, the disadvantage is that the application process can not automatically take place (Brown, 2011).Based on the research carried out by Đorđević and associates (2016), the comfort in the hotel is the most influential factor when choosing a hotel and satisfying the visitor. For years, tourists are aware of the possibility of a comfortable stay in the hotel, the ease of providing services, so it is still high on the list of guest requests today (Đorđević et al., 2016).

Interactive services based on NFC technology in cooperation with Nokia were tested in two museums in London - London Museum and London Port Museum. The NFC technology test in two museums focuses on the history of London, in August 2011. Visitors can access additional information through 90 RFID tags. In addition to various information points, tickets for the next exhibitions can be purchased and visitors can automatically like and share on social networks like Facebook, Twitter and Foursquare. In addition, the London Sound Track application can be downloaded. This application is programmed by Nokia and allows visitors to hear the sounds of earlier centuries in the history of London (Clark, 2011b).

\section{Case studies}

One of the most widely used applications of NFC technology in tourism is mobile payment. The way to use this application is primarily to enter data from credit or debit cards into a mobile application on your phone. The advantage is that the transaction is done quickly and no bugs are made on the terminals, but at the same time it is very safe because each transaction generates a unique identification number. Also, users do not have to type any code. One of the examples of such wallets is Google Wallet. It is only necessary to install an application on a smartphone (www.broadwayworld.com; McHugh and Yarmey, 2014).

Today, these two projects are integrated into one called Android Pay. This service allows Android devices to communicate wirelessly with their selling places using antennas for near-field communications, card emulation and Android security. Users can add payment cards to a service by photographing a card or manually 
entering information from the card. For payment at points of sale users keep their authenticated device up to the sales system and thus the transaction is executed.

Also, Apple Inc. has developed its own digital wallet called Apple Pay, which allows users to pay with Apple iPhone, Apple Watch, iPad and Mac. The service retains the customer's payment information so that the trader cannot access this information, because for each transaction a dynamic security code is generated.

EpicMix is an application for mobile phones designed for use on ski resorts, presented by Lindsey (2010). It was launched under the slogan Record.Connect.Share in 2010to help users share statuses, comments about skiing and a ski center on social media. The application is offered to the Vail (Colorado) ski resort. In infrastructure terms, all 89 lifts on all five tracks are equipped with RFID scanners. Mobile applications can be linked to Facebook and Twitter. The lift card stores ski passes and location-based information. When the person passes an RFID detector, its location is shifted to the application. Since there is a developed Wi-Fi link on the ski slopes, it is possible to communicate with people that are on the mountain at that time, as well as connecting, sharing and sending messages via an application or other social network. They can also receive information about weather forecasts, traffic and conditions on the paths through the application.

The application is compatible with Android and iOS. This shows that the application's service is focused on a passive RFID mode, because the iOS system does not support NFC technology. The EpicMix application resembles site-based social networking applications such as Foursquare. The difference is that the login process is automated and the settings are related to skiing. Therefore, the user does not have to actively use the service. It is possible to look at where you were going during a skiing after a visit, because the location information is stored automatically on the EpicMix account (Keeneth, 2011).

It is planned that the system will expand,so there are RFID scanners not only at the entrances, but also in other locations to allow accurate tracking of the person. This could also lead to a situation where virtual and real experience is combined, e.g. rewarding active skiers with free drinks in a ski bar (McCarthy, 2011).

Since September 2011, Scandinavian Airlines System- SAS has been using NFC technology. In order to ensure as simple as check-in and check-out of passengers at the airport, as well as luggage control, smart stickers are created that can be used by all loyal travelers. Stickers are placed in many places at the airport, when buying on self-extinguishers, in bars, shops, at gates. "Our customers really appreciate our mobile travel solutions and we can see that your mobile and NFC is the future," said vice president of product and customer service. "We are therefore proud to be one of the first airlines in the world to offer such a smart solution as the SAS Smart Pass to our most frequent travelers, making their journey even smoother. The trial period earlier this year clearly showed that customers enjoy the product and that SAS is once again meeting customer's expectations." (www.nfcworld.com). 
On the occasion of the Olympics and the World Football Championship, a project Rio Smart City was launched in Rio to provide easier access to information and information in the city to visitors. This project was also used extensively for the citizens of Rio, as they were able to use all the services of the project, and thus to ease everyday life. Part of the project consisted of a map of the city with identified public transport operators, driving schedule, significant tourist destinations, good food restaurants, and etc. In particular, during the World Cup football championship, the timing of all matches and events related to the championship were available on the application. Such a project was the first in Latin America, which in some ways digitised one city and enabled greater accessibility of information of importance to tourists and citizens (www.connecthings.com).

In Spain, a smart poster for NFC technology users has been installed at the Port de Soller Resort, in Aimia Hotel. Tourists in this way can get information about excursions, the best tourist destinations in the surrounding area, tourist organization, weather forecast, internet access network, city map. Smart posters are set up within the hotel, thus enabling quick check-in and check-out from the reception. For guests who do not have smartphones equipped with NFC technology, there are QR codes, so that everyone can access information and services (www.nfcworld.com).

In the oldest part of the city of Sydney, but also a tourist highly visited, known as The Rocks, a virtual route for visitors has been created. The route consists of 37 important places to visit, with NFC technology and QR codes for reading, so that the tour of this part of the city will be presented to tourists in a more fun way providing important and interesting information. "With just a simple tap of their mobile phone, visitors will be taken on a journey through laneways of The Rocks, along cobblestone streets and up and down sandstone steps to reveal fascinating stories of families, friends, convicts and colonists," said the Minister of trade and investment."We anticipate the new technology will offer the 14 million visitors who come to The Rocks each year a richer experience and encourage them to spend more time in the precinct," he adds. "This is just the first stage in an exciting technology development in The Rocks, with future plans to introduce video, audio and bi-lingual capabilities."This project has yet to expand services, to provide visitors with information about nearby restaurants, souvenir shops, additional tourist facilities, content for children, etc. For visitors who do not use smartphones, brochures are available with the most interesting places to visit, as well as restaurants and similar facilities (www.nfcworld.com).

In 2003, Shibuya Clickable Project was launched. It is presented with NFC stickers in certain parts of the city, placed on the streets accessible to anyone using smart devices with NFC technology. Stickers contain different information, from local importance to tourist information. So, for example, they could get job offers. Therefore, these streets looked much more beautiful compared to others, because they were not leaked with various advertisements and other offers. Also, by 
scanning this sticker people could see where they are currently located, a part of the city, the name of the street, what is nearby, then various offers for lunches, dinners, lower prices in stores and boutiques. All the companies that participated in the project could advertise through stickers and send their offers (www.cyberagent.co.jp).

The following text will present examples of implemented beacon technology in different tourist destinations across the world, which helps in enriching the tourist experience.

Luxury Atlantis Resort, located in Dubai, takes advantage of beacon technology and the advantage of virtual reality in order to improve the experience of its users, as well as improve their brand. Atlantis Resort has set an electronic beacon through its entire location, wherever the guests pass through and interact at certain points. Lost Chambers Aquarium, located within this resort, has its own application designed to be fun and educational. It is made in the form of a game on a mobile phone that uses beacon technology in order to communicate with guests in an interesting way, according to their location in the aquarium (Stamenkovic, 2016; Babu, 2015).

At the airport in Singapore, called Changi, beacons were placed in the floors and on the walls. Beacons send information to travelers on their smartphones, in the area where they are currently located within the airport. In this way travelers have information about time remaining to flight, the time it takes to get to the boarding gate and other important information. Their application has the ability to display information in different languages (Stamenkovic 2016; Babu, 2015).

For the leading Dutch operator, an application called Corethree has been created, which, with the help of installed beacons, provides information to travelers. In relation to where person travels, the user gets information about discounts, good places to visit. For loyal users of this application, users get certain benefits. Within this project, 3000 beacons were installed in the Netherlands (Stamenkovic, 2016; Babu, 2015).

To digitize Queensland territory in Australia, beacons were set up. Through beacons tourists can very easily travel around this territory, find interesting places and contents, using 150 beacons. Beacons contain information that will make the visit of tourists interesting and leave a very good impression on the whole stay in this territory. Beacons are also set up at locations where various events and events are held (Babu, 2015).

One of the larger chains of hotels and resorts, Starwood, has installed beacons for iOS operating systems, so that every user of their services in the hotel and resort will get as good as possible experience. First of all, through the beacon, each guest receives a welcome message when entering their facilities, then a quick 
check-in to the hotel without waiting at the reception, and a number of other information relevant to tourists (Kharif, 2014).

Visitors of the museum in Antwerp, Belgium, can use virtual guidebooks, in order to be able to choose what information they want about art and cultural heritage (Brown, 2014). This virulence guide is provided by installed beacons inside the museum's premises. This way of providing information to tourists is well accepted, and therefore more and more tourism representatives are identifying beacons in order to enrich the tourist experience at the destination or in individual facilities.

The SAIL Amsterdam event is organised every five years. In August 2015, it was an event with presenting beacon technologies. Based on the biggest Beacons promotion event in the world in Amsterdam, we can conclude how much attention is paid to the promotion and development of contactless technologies. This event was attended by 2.5 million people, who could participate in various interactions with the help of beacons. They also received information about ships in the harbor, the following events, as well as all other information related to the port (Nabben et al., 2016).

The first airport that dared to place beacons and so ease many processes was the International Airport in Miami. "Miami has made it easy for airlines and other partners working at the airport, to take advantage of iBeacon technology and provide information that is relevant to the passenger's location or stage of the journey," said chief technology officer. "And, of course, it is not just for passengers; beacons can be used for staff notifications and to spread operational information - such as temperature, noise levels, vibrations, etc. - throughout the airport to allow efficient operational management"(Garcia, 2014; Moody, 2015).

In an interview with the International Airport Review magazine, representatives of the Miami International Airport explained that beacon technology helped in their services in various ways. Beacons have made it possible to meet the expectations of airport users, and even overcome them. Users are provided with information of flights, flight time / landing time, the remaining time for passing the gate, suggestions of shops and restaurants within the airport, flight searches by destination or number of flight, information on allowed luggage, luggage prices, navigation within the airport to reach specific points of interest, creating a user profile that preserves our data on the use of airport services. According to the statistics, this application has been downloaded from the beacon 140,000 times since 2014(www.internationalairportreview.com).

The entire tourism industry relies on visitors being able to find the right location with ease, yet one key pain points for tourists is simply finding their way on a daily basis. In 2015, a project was implemented at the famous Spanish wine route, Ribera del Duero, to help tourists get around the area. Beacons helped users answer questions like "Where am I?" or "What am I looking at?" This new communication 
campaign helped grow the number of visitors from 83,000 visitors in 2010 to 269,000 in 2015. This helped to increase revenue per year, but also to create new jobs (www.kontakt.io).

For the city of Wellington, wayfinding with beacons meant giving new opportunities to vision-impaired residents. In a great case of "go big or go home", the city decided to set beacons all over town. Backed by the Wellington City Council, the project deployed 200 beacons in the central business district. This project has been praised by the local community because it has presented Wellington in the best light through digital technologies and because it enables visual-impaired population to use this technology. The application is made to give the information, by the speech, about the environment in which the user is currently located. It can serve as audio navigation, to pronounce the names of shops and other objects through which the user passes, the names of settlements, streets, squares, bus stops, taxi carriers, e.g. what restaurants have to offer. The project was primarily created to present the use of beacon in one object, i.e. what can be offered by the beacon. (www.kontakt.io).

Nestled between the medieval centres of Siena and Florence, the Chianti Classico region is known for its lush vineyards and varied soil and topography, producing premium wine celebrated the world over for its delicate, floral and nutty notes. Now visitors to the region will have access to a wealth of information about the history and production process of different Chianti wines, as well as a detailed guide to the entire Chianti region. The application acts as a personal tour guide, with Kontakt beacon technology enabling users to download hyper-local content straight to their phone. The user will be able to read the tasting notes and learn more about the grapes used to make the wine they are currently sipping, under a glorious Italian sun. Bringing together knowledge from leading oenologists and vineyard owners in the Chianti region, the application is the go-to guide for tourists paying homage to the area's most prized produce. For visitors to the Chianti Classico region, a wine-tasting session in the Crystal Lounge of Florence's Stadio Artemio Franchi is a sure highlight. As well as enjoying an unrivalled view of the pitch and excellent food, drink and company, visitors will also access relevant articles and exclusive multi-media content through the beacon-enabled Chianti Classico application. Since its inception in 2015, the Chianti Classico application has enjoyed a huge following among wine "aficionados", as well as accolades from publications including This is Italy and The Drinks Business. The Chianti Classico Wine Consortium noted a $100 \%$ increase in downloads over the three-day 45th Chianti Classico Expo, a testament to the application's reputation among Chianti connoisseurs (www.kontakt.io).

The Museum of Art in Philadelphia created a special offer for family visits, the application "A is for Art Museum" which creates an interesting guide through the museum to family members, which is also adapted to the children at the same time. A game was created in which visitors should find by name 26 works of art located 
in the museum. Also, beacons provide information on works of art, the following exhibitions, discounts and early bookings. (www.kontakt.io).

MOCAK, the Museum of Contemporary Art in Krakow, Poland, deployed beacons next to selected exhibits to provide more information about artworks and their authors. When a visitor approaches a beaconised piece of art, an application developed by HG Intelligence triggers a notification with an incentive to learn more. After tapping on it, the user can read a detailed description, interview with an author or other works by the artist (www.kontakt.io).

The City of Edinburgh guides its visitors through the Royal Mile on mobile without the Internet connection. The Edinburgh Up Close application, developed by Neatebox, takes city tours to the next level by making them personal, available to everyone (also to sight and hearing-impaired users) and possible to walk through at one's own pace. Beacons deployed along the Royal Mile trigger information and stories about streets, buildings and museum that a user passes by. All the pieces of content may be read or listened to, accessed with or without the Internet connection, and consumed immediately or saved for later (www.kontakt.io).

Thanks to the app by epunched.com, Attendees of The Garden Center Group's fall event in Orlando could not only enjoy the conference-related features, but also go for a VIP tour guide around the SeaWorld. Tough Beacons located at the park marked key places and help the users navigate the area. After reaching one of these points, a user had to interact with content in order to get directions on how to get to another (www.kontakt.io).

The Palace of Venaria is a XVII-century royal residence that attracts visitors by its great story and beautiful architecture. To encourage the visitors to explore both, the palace staff rolled out the La Venaria application developed by Smart Beacon. Thanks to beacons installed on site, the app shows a map of available attractions that get unlock only if a user visits them (www.kontakt.io).

Beacons are also deployed in other major airports: Amsterdam Schiphol, Gatwick London (UK), Hamburg (Germany), Mexico, Moscow (Russia), Mumbai (India), San Francisco (California), Tegel Berlin (Germany).

\section{Contactless Technology - statistics}

With technological developments happening at a fast pace, more and more payment methods enter the retail market. In recent years, for example, the number of available mobile payment applications in the Benelux countries steadily increased. The contactless payment method is used a lot in the United Kingdom, where 23 percent of the respondents indicated they used this payment method several times per week. With the Benelux region being in close proximity to the UK, the question begs itself whether Belgium, Luxembourg and the Netherlands 
also use contactless payment methods. Contactless payments are relatively new in Belgium and no numbers on this topic are available as of yet. It is estimated that by the end of 2017 all POS terminals in Belgium will support NFC. Payment company CCV Belgium estimated in April 2017 that approximately 0,27 percent of all their processed payments were contactless, showing that as of yet the market for contactless payments in Belgium is small. This could change in the future, however, as Belgian consumers gain more familiarity with new payment technologies. Since the summer of 2017, for example, Belgian banks and retailers started to accept Android Pay. Also, mobile payment methods in general appear to be on the rise in Belgium, as respondents to a large e-commerce survey indicated an increased use of their bank's app along with PayPal in 2017, compared to 2016. NFC use could benefit from these developments, but time will have to tell.

The same goes for Luxembourg: contactless payments are relatively new. The first credit cards with NFC-technology were issued during the early months of 2016 and it's during 2017 that debit cards are going to receive this as well. Luxembourg newspaper mentions that during the whole of 2016, NFC made up approximately 1.28 percent of all transactions, reaching 3.55 percent of the transactions done in the month of December. High value transactions were conducted the least by customers in the Grand Duchy, as transaction amounts between 100 and 200 Euros consisted of four percent of all contactless payments. Instead, credit cards were indicated to be the preferred method of payment by 34 percent of respondents. In 2016, 64 billion credit card transactions were made, both domestic as well as abroad.

NFC is popular in the Netherlands, with support and development coming from domestic banks in the absence of Android Pay, Apple Pay and Pay from Samsung. NFC payments were introduced in the Netherlands in 2014 and since then its use has increased. In the second quarter of 2015, 2.3 percent of the total debit card payments consisted of NFC payments. Two years later, this had increased to a share of 32 percent. In 2016, 50 percent of all contactless payments had a transaction amount of ten euros or less. Between the first quarter of 2015 and the first quarter of 2017, the total number of registered NFC payments in the Netherlands increased from 10.5 million payments in 2015 to 251 million payments in 2017. Despite this popularity, the majority of consumers only uses this technology with their debit cards. Roughly 70 percent of respondents in the Netherlands indicated they never used mobile phone payments before, indicating this is an area where NFC could still improve. This was confirmed in November 2017, when the Dutch Payments Association announced 320,000 Android-users used their smartphone for NFC payments (www.statista.com).

Based on UK research on the application of contactless technology after the increase in the limit during one transaction, it can be concluded that each category has achieved a certain increase in consumption, so in pubs and bars more than $90 \%$ of the increase in consumption has been achieved, while in supermarkets, Fast food 
restaurants and fine dining restaurants have increased consumer spending by more than $50 \%$ per category (www.finextra.com).

Based on Barclaycard research, nearly $60 \%$ of surveyed retailers believe that users are much more inclined to use smartphones as mobile wallets when paying. It is believed that in the coming years people will use these payment methods more and more, because there are more than 250.000 terminals in the UK, where mobile payments can be made by the company that conducted this research. Also, this led to the conclusion that only $35 \%$ of retailers accept the non-contact payment method, while a very small percentage is still distant from this technology (www.finextra.com).

The survey (Picture1) is taken worldwide. The key findings are based on an online survey of 101 senior IT executives representing more than 223 airports worldwide. The airports participating in the survey represent $37 \%$ of the global traffic based on passenger traffic data from Airports Council International (ACI).

Picture 1. The result of a survey regarding end-to-end beacon deployment at airports worldwide in 2015 and 2018

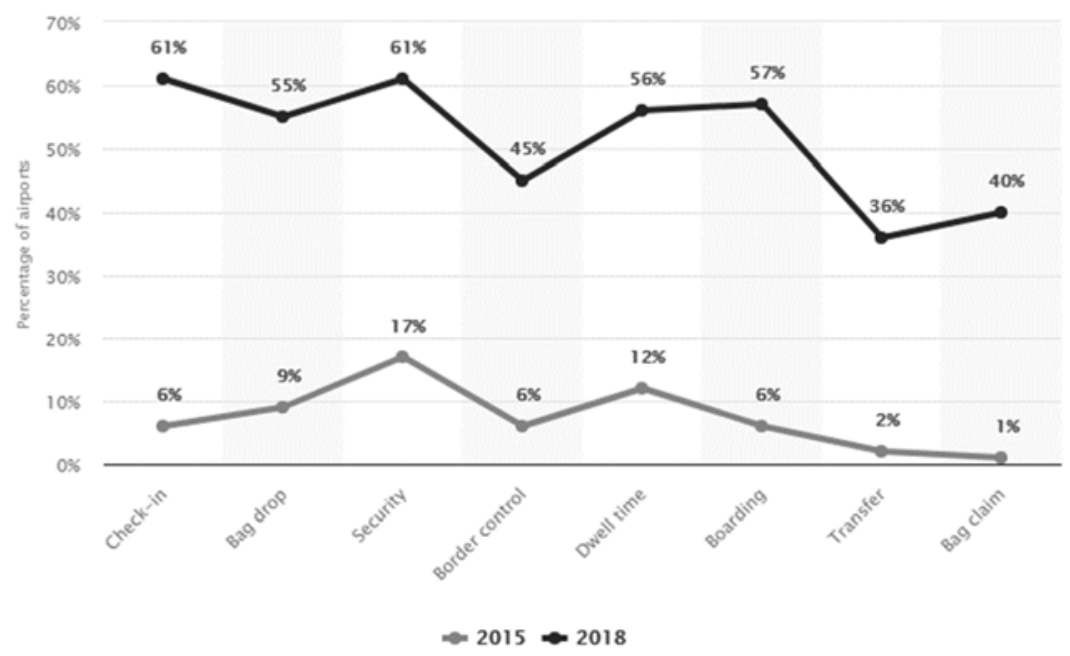

Source: www.statista.com

This statistic shows the result of a survey regarding end-to-end beacon deployment at airports worldwide in 2015 and 2018, by stage of journey. The results show that there is a strong tendency among airports towards leveraging beacon technology at each stage of the passenger's journey. By 2018, it is expected that more than 60 percent of airports will have deployed beacon technology at check-in and security. 


\section{Future directions}

In this chapter, possible ways and directions for the development of contactless technology will be discussed. NFC technology is likely to become a desirable function for every smartphone, as it will probably be possible to carry out everyday obligations through this technology, such as paying obligations, communicating with the closest ones, using passports and other personal documents, tracking people using a fingerprint. Many actions can be assured through smartphones and NFC technology, but it will take time for people to accept this technology and trust it completely, without any prejudice. We know that communication with others is very easy today and that there are no geographical constraints, and in time, the use of this technology will also become an everyday one. What needs to be pointed out here is the security provided by this technology when exchanging data between two devices, because it requires proximity that will also allow data exchange in the future that should be protected in some way (Ok et al., 2010).

By research of SITA Laboratory it has been determined that the installation and management of beacons significantly reduces the cost of sharing information to passengers or airport users(www.kontakt.io).Also, research shows that users value this technology and find it very useful. Beacon technology is not only useful for travelers, but also for the cooperation of the airport with other companies, because through beacons they can advertise all facilities within the airport, as well as other companies. This is certainly a good way to advertise hotel and restaurant services, which will probably become a marketing tool at airports in the coming years because of the high fluctuation of passengers (Moody, 2015).

It was only recently that 2,000 Kontakt beacons were deployed in London Gatwick and there is plenty more to come. In fact, BI Reports predicts more than $90 \%$ of global airports to have navigation included in their mobile apps in 2018. As the shift to mobile continues, airport operators are realizing the importance of delivering information right to the customer's phone. With new deployments happening every week, it won't be long before passengers get to experience different beacon use cases in every airport they visit (www.kontakt.io).

\section{Conclusion}

For tourism, contactless technologies, especially NFC and beacon can help determine the quality of service, branding and marketing. For example, "Cityzi" logos can be sued for marketing purposes. Contactless technologies also enable travel without paper, making the mobile phone all that tourist need at the destination, also for those travelling to certain technologically advanced destinations. Contactless technologies can reduce the number of actions a user has to perform, thereby increasing user experience and providing a secure and easy way to share information, as well as a way to facilitate the adoption of technology. 
Research of how to use contactless technology in tourism is an important topic for the future. There are currently more applications in the real world than there is a study of the use and usability of these technologies. If the number of devices that support NFC continues to increase, it is only a matter of time before the device will appear, which creates enough opportunities for companies to start using NFC in even more profitable ways will appear. These technological achievements will permanently influence tourism practice.

Beacon technology has begun to evolve, and therefore there are barriers to the acceptance of this technology in humans, primarily because of security, but also because of lack of knowledge. Especially, beacon technology that is relatively new, offers great opportunities, but there are many shortcomings. For this reason, NFC technology is mostly used in tourism and is presented as a leader. Users are often unaware of how to properly use a particular application and, for example, do not allow the Bluetooth feature on their phones. It is necessary to find a way to provide people with the necessary information of the use of technology, so that the creators of beacons can implement beacon technology in as many ways as possible and on hundreds of locations worldwide. Some users consciously give up certain elements because of their privacy by transferring applications to their smartphones, such as location, but may not realise that it significantly limits the advanced application capabilities. Based on the theoretical analysis of contactless technologies, as well as its practical applications in tourism presented in this paper, numerous advantages of usage are noted, both for tourism companies and for the tourists themselves, that is, consumers in the wider sense. The examples in this review can represent lighthouses for tourism companies and other factors of tourism development in countries with a weaker information technology infrastructure and consumer literacy, among which is also Serbia.

\section{References}

Babu P. (2015). How Beacons Transforming the Travel Industry, available at: http://blog.beaconstac.com/2015/11/how-beacons-are-transforming-the-travelindustry/, accessed: November 15, 2017.

Balaban, D. (2010). Frenchmake it official with Nice NFC launch, available at: http://www.nfctimes.com/news/french-make-it-official-nice-nfc-launch, accessed: August 10, 2017.

Basili, A., Liguori, W. \& Palumbo F. (2014). NFC Smart Tourist Card. Combining Mobile and Contactless Technologies towards a Smart Tourist Experience (pp. 249-254). Parma, Italy: IEEE 23rd International WETICE Conference.

Brown, C. (2011). NFC room keys find favour with hotel guests, available at: http://www.nfcworld.com/2011/06/08/37869/nfc-room-keys-find-favour-with-hotelguests/

Brown, M. (2014). Location, Location, Location. Canadian Business, 12-14.

Buhalis, D. \& O‘Connor, P. (2005). Information Communication Technology Revolutionizing Tourism. Tourism Recreation Research, 7-16. 
Buhalis, D. (1998). Strategic use of information technologies in the tourism industry. Tourism Management, 409-421.

Clark, S. (2010a). NFC city pilot to go live in Nice on 21 May under 'Cityzi' banner, available at: http://www.nfcworld.com/2010/05/14/33638/nfc-city-pilot-to-golive-innice-on-21-may-under-cityzi-banner/, accessed 10.11.2011.

Clark, S. (2011a). French carriers launch second NFC city, available at: http://www.nfcworld.com/2011/09/12/39865/french-carriers-launch-second-nfc-city/

Clark, S. (2011b). Museum of London adds NFC, available at: http://www.nfcworld.com/2011/08/16/39129/museum-of-london-adds-nfc

CyberAgent, Inc. (2013). "Shibuya Clickable Project" to Commence in June Available at: https://www.cyberagent.co.jp/files/topics/7332_ext_29_en_0.pdf

Denso, W. (2010). QR Code, Available at: http://www. denso-wave.com/qrcode/index-e.html, accessed: December 2, 2017.

$\mathrm{Du}, \mathrm{H}$. (2013). NFC Technology: Today and Tomorrow. International Journal of Future Computer and Communication, doi: 10.7763/IJFCC.2013.V2.183

Gallaga, O. (2011). Austin becomes an arena for Google's new small-business initiative, available at: http://www.statesman.com/business/austin-becomes-an-arena-forgoogles-newsmall-1251851.html, accessed May 4, 2017.

Garcia, M. (2014). Miami International Airport Makes Commitment to Beacon Technology, available at: <http://skift.com/2014/09/24/miami-internationalairport-makescommitment-to-beacon-technology/>.

Gast, M. S. (2014). Building applications with iBeacon: proximity and location services with Bluetooth low energy. Sebastopol: O'Reilly Media.

Kahveci, A. \& Okutmus, E. (2017). A qualitative research on medical tourism potential of Alanya/Turkey in the concept of international service trade. Economic Themes, 55(3), 437-450.

Kaur, M., Sandhu, M., Mohan, N., \& Sandhu, P. S. (2011). RFID Technology Principles, Advantages, Limitations \& Its Applications. International Journal of Computer and Electrical Engineering, doi: 10.7763/IJCEE.2011.V3.306

Kenneth, G. (2011). Social networking app backs up Après-ski tales, available at: http://nfcdata.com/blog/2011/03/09/social-networking-app-backs-up-apres-ski-tales

Kevin, C., Amanda, M. \& Conor, M. G. (2012). Near Field Communication. International Journal of Electrical and Computer Engineering, 2(3), 371-382.

Kharif, O. (2014). Why Apple's ibeacon Hasn't Taken Off -- Yet. Bloomberg Businessweek, 35-36.

Kneiß1, F., Rottger, R., Sandner, U., Leimeister, J. M. \& Krcmar, H. (2009). All-I-Touch as combination of NFC and lifestyle (pp. 51-55). Washington DC, USA: First International Workshop, IEEE Computer Society.

Lindsey, J. (2010). Vail's EpicMix App Brings Location Tracking, Social Networking to Ski Slopes, available at: http://www.wired.com/playbook/2010/09/vails-epicmix-app, accessed: May 4, 2017.

Madlmayr, G. \& Scharinger, J. (2010). Neue Dimensionen von mobilen Tourismusanwendungen durch Near Field Communication Technologie. In R. Egger, \& M. Jooss (Eds.), mTourism. Mobile Dienste im Tourismus (pp. 75-88). Wiesbaden, Germany: Gabler Verlag.

McCarthy, C. (2011). Vail Resorts unveils ski slope geolocation system, available at: http://news.cnet.com/8301-13577_3-20015114-36.html, accessed: June 4, 2017. 
McHugh, S., Yarmey, K. (2014). Near Field Communication: Recent Developments and Library Implications. Synthesis Lectures on Emerging Trends in Librarianship, 1(1), $1-81$.

Michelle M. (2013). Near Field Communication Smart Phones and Library RFID, available at: http://connectinglibrarian.com/2013/11/16/near-field-communication-smartphonesandlibrary-rfid.

Moody, M. (2015). Analysis of Promising Beacon Technology for Consumers. The Elon Journal of Undergraduate Research in Communications, 6(1), 59-68.

Nabben, A., Wetzel, E., Oldani. E., Huyeng, J., Boel, M. \& Fan, Z. (2016). Smart

Technologies in Tourism, available at: https:/opendataincubator.eu/files/2016/06/Smart-Technologies-in-Tourism.pdf, accessed: July 24, 2017.

Ok, K., Coskun, V., Aydin, M., Ozdenizci, B. (2010). Current benefits and future directions of NFC Services (pp. 334-338). Cairo, Egypt: International Conference on Education and Management Technology (ICEMT), IEEE

Okazaki, S., \& Hirose, M. (2009). Does gender affect media choice in travel information search? On the use of mobile Internet. Tourism Management, 30(6), 794-804.

Sen, D., Sen, P., Das, A. M. (2009). RFID for energy \& utility industries. Tulsa: Pennwell Books.

Stamenković, M. (2016). Mogućnost primene "beacon" tehnologije u turizmu - Master rad. Prirodno-matematički fakultet, Novi Sad.

Vazquez-Briseno, M., Hirata, F., Sanchez-Lopez, J., Jimenez-Garcia, E., Navarro-Cota, C., Nieto-Hipolito, J. (2012). Using RFID/NFC and QR-Code in Mobile Phones to Link the Physical and the Digital World. In: Dr Deliyannis I. (Ed.), Interactive Multimedia (pp. 219-242). Rijeka: InTech.

Violino, B. (2014). NFC Tags for New Business and Consumer Applications. RFID Journal, 11(5), 31-37.

Want, R. (2006). RFID Technology. In: Satyanarayanan, M. (Ed.), An Introduction to RFID Technology (25-33). Santa Clara, California: IEEE Pervasive Computing.

Đorđević, A., Zečević, B. \& Stančić, H. B. (2016). Importance of various service types in hotels - Empirical analysis. Economic Themes, 54 (3), 403-423.

https://www.nfcworld.com/2011/06/15/38035/sas-to-introduce-nfc-to-airports/ (Accessed: 09.09. 2017)

https://www.nfcworld.com/2013/07/24/325127/spanish-hotel-delivers-guest-information-vianfc/ (Accessed: 09.09.2017)

https://www.nfcworld.com/2012/07/02/316609/sydney-picks-nfc-and-qr-codes-to-guidevisitors-around-the-rocks/ (Accessed: 09.09.2017)

https://kontakt.io/blog/spanish-tourism-joins-the-iot/ (Accessed: 15. 11. 2017)

https://kontakt.io/blog/kontakt-io-helps-the-people-who-are-blind-explore-wellington-newzealand/(Accessed: 15. 11. 2017)

https://kontakt.io/blog/beacon-technology-and-wine-tasting-experience-for-chianticonnoisseurs/(Accessed: 15. 11.2017)

https://kontakt.io/use-cases/museums/ (Accessed: 15. 11. 2017)

https://kontakt.io/blog/airport-technology-and-bluetooth-beacons/(Accessed: 15. 11. 2017)

https://www.internationalairportreview.com/article/26192/beacons-miami-international/ (Accessed: 23.11.2017)

http://www.nfc.cc/technology/nfc/ (Accessed: 29.11.2017)

http://www.ibeacon.com/what-is-ibeacon-a-guide-to-beacons/ (Accessed: 12.12.2017) 
https://www.cisco.com/c/en/us/solutions/enterprise-networks/mobility/mobility-inhospitality.html (Accessed: 12.12.2017)

https://www.broadwayworld.com/bwwgeeks/article/Drync-App-Integrates-With-GoogleWallet-to-Make-Wine-Purchasing-Faster-and-Easier-20140821(Accessed: 12.12.2017)

https://www.connecthings.com/es/2014/06/11/connecthings-powers-rio-smart-city-5000interactive-stickers-in-rio-de-janeiro/ (Accessed: 12.12.2017)

https://www.finextra.com/news/announcement.aspx?pressreleaseid=62560 (Accessed: 21. 12. 2017)

https://www.statista.com/topics/4248/contactless-payments-in-the-benelux/ (Accessed: 21. 12. 2017)

https://www.statista.com/statistics/572632/beacon-deployment-at-airports/ Iccessed: 21.12.2017)

\section{BESKONTAKTNA TEHNOLOGIJA KAO FAKTOR RAZVOJA TURISTIČKE INDUSTRIJE: PREGLED TRENUTNIH PRIMERA I BUDUĆE IMPLIKACIJE}

Rezime: Tokom Drugog svetskog rata razvijena je tehnologija za praćenje objekata i neprijateljskih aviona, sada poznata kao beskontaktna tehnologija, koja je $u$ to vreme bila ograničena samo na jednu vrstu tehnologije, koja se naziva RFID - identifikacija putem radio-frekvencije. Sa razvojem beskontaktne tehnologije, iz RFID tehnologije nastala je NFC tehnologija, koja je označena kao tehnologija kratkog polja. Danas je još poznata i razvijena Bluetooth Beacon tehnologija. Sve tri tehnologije imaju veliku primenu u turizmu, kao što je beskontaktno plaćanje, naplata putarine, deljenje važnih informacija, kontrola pristupa, razmena podataka između dva pametna uređaja, kao i mnoge druge. Cilj ovog rada je da ukaže na značajnu primenu beskontaktnih tehnologija u turizmu, kao i da istakne prednosti i buduće implikacije pomoću predstavljenih primera.

Ključne reči: beskontaktna tehnologija, RFID, NFC, Bluetooth Beacon tehnologija, turizam, razvoj turizma.

\section{Authors' biographies}

Nataša Dragović, was born on May 7, 1994 in Loznica. She graduated in 2012 at the Faculty of Sciences, Department of Geography, Tourism and Hotel Management. At the same faculty in 2017, she completed master studies in hotel management. At that time, she was interested in information technology in tourism and started to study with the research that was originally related to the master's thesis: "Comparative analysis of contactless technology in tourism". Practical classes during the studies she performed at the restaurant "Alaska Barka" and the restaurant "Ribarac" in Novi Sad, in the hotel "Aqua Premier" in Vrdnik, the canteen of the Faculty of Sciences in Novi Sad, hotel "Termag", Jahorina in the Republic of Srpska, hotel chain "LifeClass" in Portorož in Slovenia, restaurant "LaBocca" in Budva, Montenegro. She speaks English and Russian. 
Uglješa Stankov is Associate Professor at University of Novi Sad, Faculty of Sciences, Department of Geography, Tourism and Hotel Management. His main research interests are ICT applications in tourism and travel industry, Internet marketing and geo-information technology. He is the author or coauthor of more than 100 scientific publications.

Đorđije Vasiljević is assistant professor at the Department of Geography, Tourism and Hotel Management, Faculty of Sciences, University of Novi Sad where he lectures courses Geoheritage Conservation, Selective Forms of Tourism, Festival Tourism, IT in Tourism, Wine Tourism. His main field of study is geoheritage and geotourism, from which he published 19 research papers at journals with international significance and more than 200 citations in Scopus database. He is also author of 3 book chapters in monographs published in the UK. Apart from research, he is also a member of National project funded by Ministry of Education, Science and Technological Development of Republic of Serbia (project number 176020) and Erasmus+ CB in HEI (CULTURWB No. 574193-2016). Đorđije has immense experience in event management - several important international conferences regarding research in tourism and geosciences. Additionally, he is an expert in graphical/web design and IT. 